\title{
Remote Sensing and GIS applications for analysis of land use suitability
}

\author{
Mohamed E. Ali ${ }^{1}$, Omar H. M. El-Hussieny ${ }^{1}$, Heba S. A. Rashed ${ }^{1}$, Elsayed S. Mohamed ${ }^{2}$, Omnia H. E. Salama ${ }^{2}$ \\ ${ }^{1}$ Soil and Water Department, Faculty of Agriculture, Moshtohor, Benha University, Egypt. \\ ${ }^{2}$ National Authority for remote sensing and Space Science, (NARSS), Cairo, Egypt. \\ Corresponding author: heba.abdelmaabood@fagr.bu.edu.eg.
}

\begin{abstract}
:
The rapid development of remote sensing technology and gradually maturing of GIS technology applications provides the foundation for land use suitability from the qualitative analysis to quantitative analysis. The use of remote sensing technology, GIS technology in land suitability evaluation is a new technology. The present study is a qualitative evaluation of land to determine land capability and land suitability in southern Suez Canal area for wheat, maize, cotton, rice, onion, alfalfa, potato, tomato, citrus cultivation. Taking land use information from study area through land use interpretation of 2013 ETM image and pedological variables, like Nitrogen-Phosphorus-Potassium $(\mathrm{NPK})$ status, soil reaction $(\mathrm{pH})$, Organic Carbon (OC) and soil texture that are mandatory input factors for land suitability evaluation through remote sensing and GIS analysis. All these factors have been rated based upon the proposed method of Sys et al (1993). The qualitative approach given by FAO (1976) has also been used to classify the land on the basis of their suitability ranked classes (e.g. S1, S2, S3, S4, N1 and N2). The result indicated that only $18 \%$ of agricultural land can be demarcated as highly suitable for rice cultivation whereas $33 \%$ of agricultural land as highly suitable for wheat cultivation in the study area.
\end{abstract}

Keyword: Land capability, Land suitability, Remote sensing, GIS, Port Said.

\section{Introduction:}

Efficient management of natural resources is essential for ensuring food supplies and sustainability in agricultural development. The task of meeting demand without affecting the ecological assets for future generations is being given top priority by both scientists and planners. There is an urgent need to match the land resources with the current land use for sustainable production and to meet the needs of society, while conserving fragile ecosystems (FAO 1993). The land capability evaluation characterizes and appraises land development units from general point of view without taking in consideration the kind of its use. There are defined classes ranging from I to VIII (Landon, 1991). This classification is useful as some soils can be suitable for specific crops and unsuitable for another's; therefore precision of land utilization types is necessary. It cloud be expressed not only in terms of types of crops productions, but also how this specific crops are produced (Sys et al., 1991). Land capability is governed by the different land attributes such as the types of soil, underlying geology, topography, hydrology, and etc. These attributes limit the extents of land available for various purposes and the optimum and proper utilization of its resources is inevitable. AbdelRahman (2009 and 2014) the actions of planning and managing the use of natural resources are of primary importance nowadays to integrate and focus the generation of geo-information to develop or improve the policies for a sustainable development in Egypt.

Land cover is the product of human activities changing terrestrial ecosystem and is an element of complex ecological and economic system that needs periodic evaluation. Knowledge about the optimal allocation of land is important for understanding the magnitude of maximum return. AbdelRahman (2009) land limitations may include a single land characteristic, e.g., (soil depth) or a land quality, i.e., (combination of individual land characteristics). Land use suitability was variously studied taking environmental variables such as topography, soil, vegetation and landforms into consideration. However, the integration of various variables for a single assessment cannot result in accurate and efficient results unless Geographic information system (GIS) is used. GIS has found several applications in land suitability studies (Pereira and Duckstein 1993; Steiner et al., 2000; Zhang et al., 2011 and Joerin et al., 2001). In order to utilize the land resources in sustainable way, a land-use plan that incorporates the different land characteristics has a paramount importance. To incorporate the different land attributes that differ spatially and to identify the best suitable land use, GIS has proved to be the best. Geographical Information system (GIS), which incorporate database systems for spatial data, were designed and developed enabling the acquisition, compilations analyzing and displaying topological interrelations of different spatial information. Moreover the surface and overlay analysis capabilities 
in GIS can effectively facilitate in handling vast amount of spatial information (Ekanayaki and Dayawansa, 2003).

The aim of the present study is to develop a remote sensing and GIS based approach for land suitability assessment of some crops, which will provides information at local level which could be utilized by farmers for selecting the proper cropping pattern to overcome the major pedological constraints.

Materials and Methods:
The study area is located to the northeastern part of the Nile Delta, south of EI-Salam canal and extends towards the northern edge of Ismailia Governorate. It is bounded by longitudes $32^{\circ} 04^{\prime} 32^{\prime \prime}-32^{\circ} 20^{\prime} 02^{\prime \prime} \mathrm{E}$ and latitudes $30^{\circ} 45^{\prime} 00^{\prime \prime}-31^{\circ} 20^{\prime} 00^{\prime \prime} \mathrm{N}$ (Fig. 1) with a total area of about 66,000 ha. According to the Egyptian Meteorological Authority (1996), the area receives a total annual rainfall of about $33.3 \mathrm{~mm}$ at Ismailia with the precipitation not equally distributed throughout the rainy season. The average annual mean temperature is $21.77{ }^{\circ} \mathrm{C}$ with a wide difference between summer and winter month.

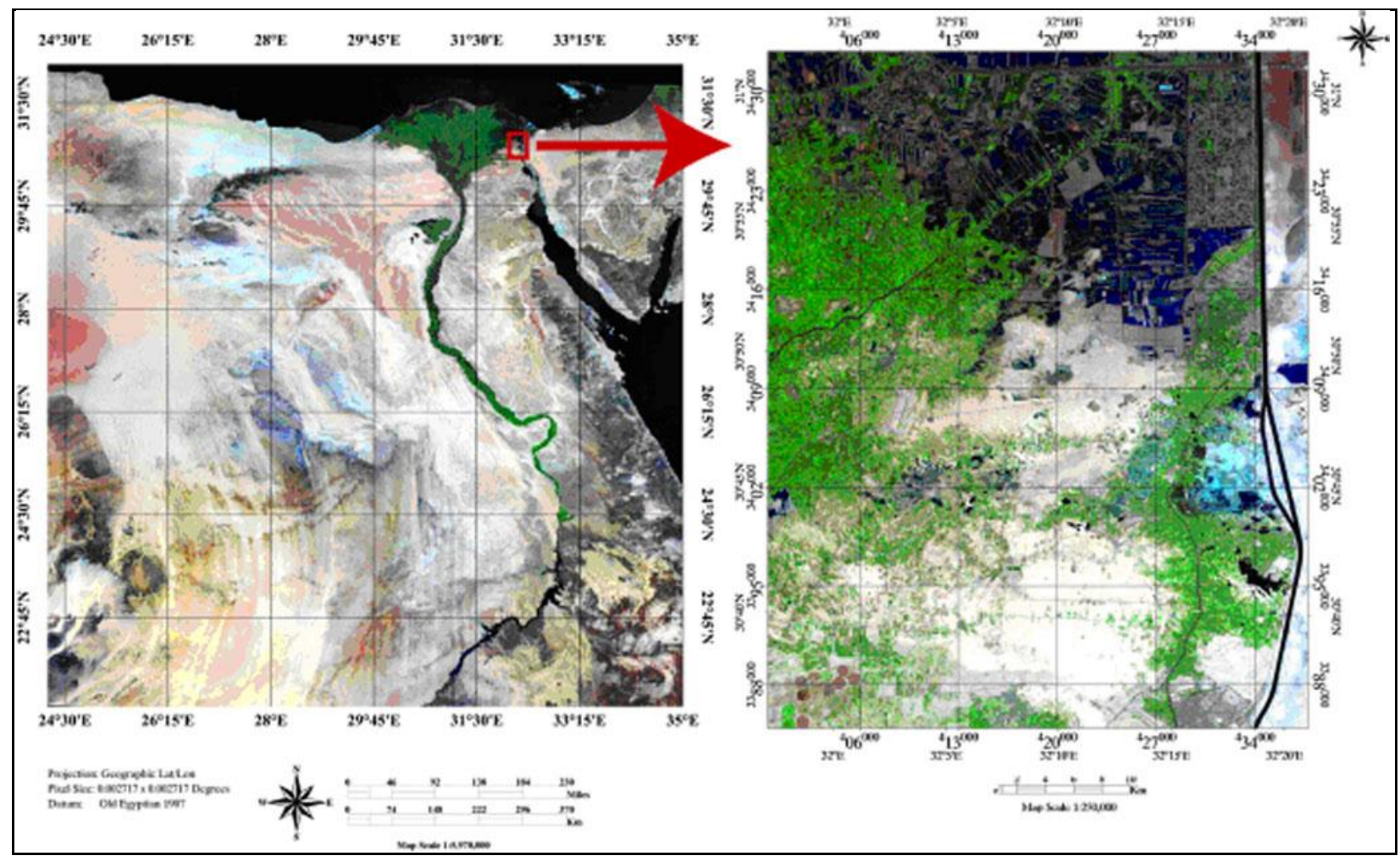

Fig. 1: Location of the study area.

Field work and laboratory analyses.

Morphological description of 23 soil profiles representing the different geomorphic units were carried out according to the field book for description and sampling soils of the USDA (2002). The laboratory analyses were carried out using the soil survey laboratory methods manual of the USDA (2004). The soil types are classified to the sub-great group level on the basis of the key to soil taxonomy of the USDA (2010).

\section{Geology}

The area located east of Nile delta is characterized by the following geological units according to (Conoco, 1987) as shown in figure (2).

1-Nile silt or Nile deposits: these geologic units occupy a large area in the Nile Delta. It have fine grained sediments (silt and clay) deposited from suspension on a flood plain by floodwater.

2 - Quaternary deposits: Quaternary deposits are common on lower part of the present land surface.

3 - Sabkha deposits: Sabkha deposits are flat and very saline areas of sand or silt laying just above the water table and often containing soft nodules and veines of gypsum. 
4 - Sand dunes: This unit represents a ridge of sand created by the wind; found in desert or near lakes. 5 - Stabilized dunes. Dunes were moved by the wind action and the stabilized by vegetation.
6 - Wadi deposits: Wadi deposits occurred where, after heavy rains, the drainage from the uplands was brought down the coarse textured sediments forming wadi.

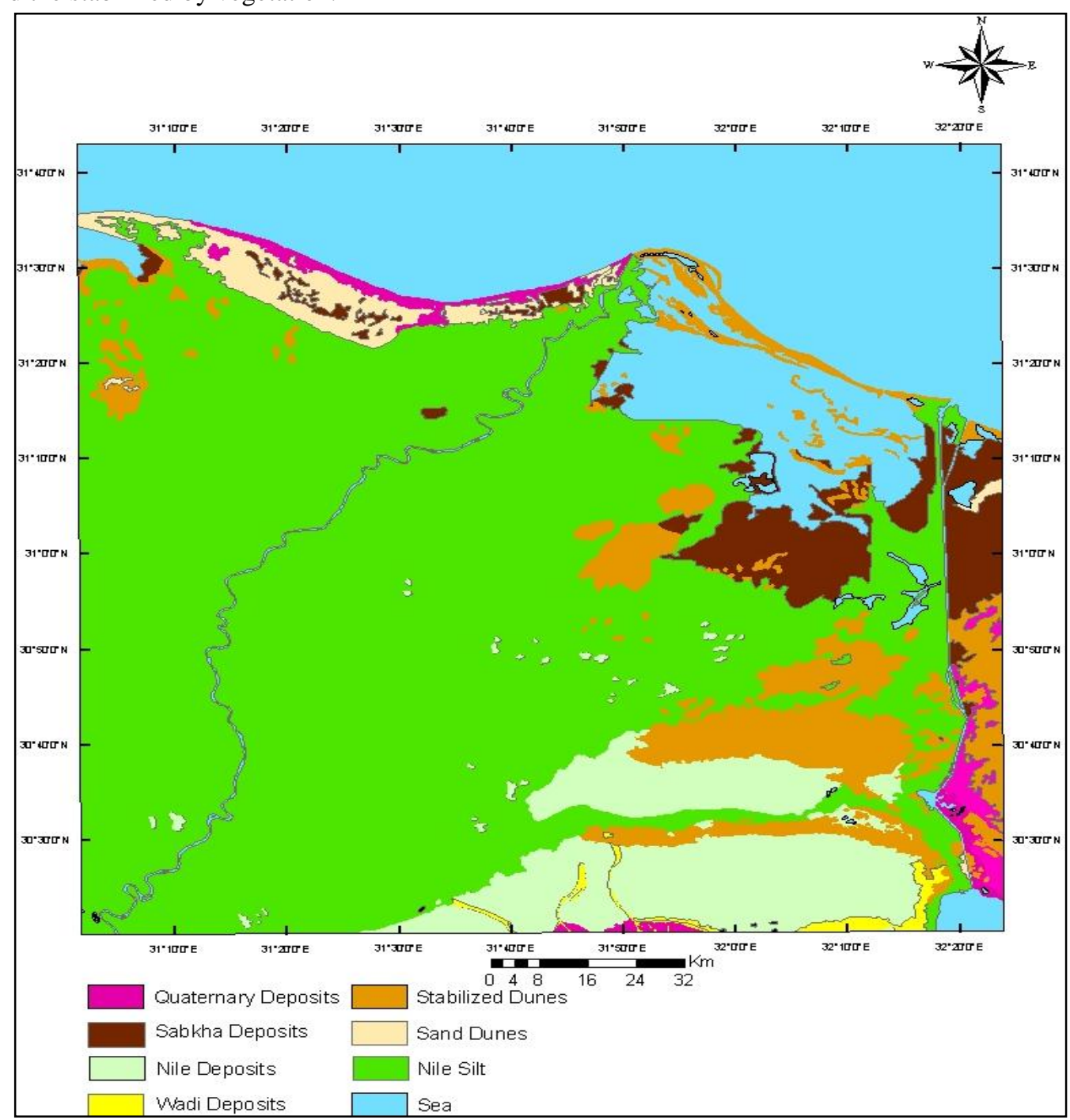

Fig. 2: Geologic map of East Delta (After Conoco, 1987).

\section{Land Evaluation}

FAO framework (FAO, 1976) was used to assess and characteristics soil of the investigated area. The aim of this system was to provide a method forecast the general land use capability for a broad series of possible agricultural uses. Where it works interactively, comparing the values of the characteristics of the landunit to be evaluated with the generalization levels established for each capability class. The factors influencing the soil suitability were used according to the FAO framework for land evaluation which include the following: Soil properties: Physical properties that determine the soil-water relationship in the soil (e.g. clay content, number of layers, soil depth, land form, level of surface and slope), chemical properties (e.g. salinity, alkalinity, $\mathrm{CaCO} 3$ content and gypsum content. The capability evaluation includes six capability orders for agriculture and reclamation land capability which are excellent $(\mathrm{C} 1)$, good (C2), Fair (C3), poor (C4), very poor (C5) and Non-agriculture (C6) (Table 1). 
Table 1.Land capability index and ratings

\begin{tabular}{ccc}
\hline Class & Description & Rating $(\%)$ \\
\hline C1 & Excellent & $>\mathbf{8 0}$ \\
C2 & Good & $<\mathbf{8 0}->\mathbf{6 0}$ \\
C3 & Fair & $<60->40$ \\
C4 & Poor & $<40->20$ \\
C5 & Very poor & $<20->10$ \\
C6 & Non-agriculture & $<10$ \\
\hline
\end{tabular}

The capability index $(\mathrm{Ci})$ is calculated, and this value is also integrated in the definition where:

Capability index $(\mathrm{Ci})=[\mathrm{t} *(\mathrm{w} / 100) *(\mathrm{~S} 1 / 100) *(\mathbf{S ~ 2 / 1 0 0}) *(\mathrm{~S} \mathrm{3/100}) *(\mathbf{S ~ 4 / 1 0 0}) *(\mathrm{~S} \mathrm{n} / \mathbf{1 0 0}) *(\mathrm{n} / \mathbf{1 0 0})$

In light of the calculated $\mathrm{Ci}$ values, the orders and classes of lands can be distinguished as follows: Class $\mathrm{C} 1$ : land units without limitations $(\mathrm{Ci}>80)$. Class $\mathrm{C} 2$ : land units with one slight limitation ( $\mathrm{Ci} 60$ to 80). Class C3: land units with more than slight limitations and more than moderate limitations ( $\mathrm{Ci} 40$ to 60). Class $\mathrm{C} 4$ : land units with more than moderate limitations and /or one severe limitation that do not exclude the use of the land ( $\mathrm{Ci} 20$ to 40). Class C5: land units with one or more severe limitation that excludes the use of the land, or with one or more severe limitation $(\mathrm{Ci} 10$ to
20). Class C6: land units with severe or very severe limitations that cannot be corrected $(\mathrm{Ci}<10)$. The land use requirements were matched to the land characteristics to determine its suitability and on the different agricultural uses. The suitability classes for each crop are: highly suitability (S1), soils with suitable (S2), moderately suitability (S3), marginally suitability (S4), no suitability (NS) include currently non suitable (NS1) and permanently non suitable (NS2) (Table 2).

Table 2.Land suitability index and ratings

\begin{tabular}{lll}
\hline Class & Description & Rating $(\%)$ \\
\hline S1 & Highly suitable & $>\mathbf{8 0}$ \\
S2 & Suitable & $<\mathbf{8 0}->\mathbf{6 0}$ \\
S3 & Moderately suitable & $<60->\mathbf{4 0}$ \\
S4 & Marginally suitable & $<\mathbf{4 0}->\mathbf{2 0}$ \\
NS1 & Currently non suitable & $<\mathbf{2 0}->\mathbf{1 0}$ \\
\hline NS2 & Permanently non suitable & $<\mathbf{1 0}$ \\
\hline
\end{tabular}

Source: FAO, 1976 and Sys et al, 1993.

\section{Results and Discussion}

\section{Geomorphologic features.}

According to EI-Fayoumy (1968) and Mohamed

(2006) there are three major geomorphic units in east of Nile Delta (Fig. 3), namely: 1-Young deltaic plain.2Old deltaic plain. 3-Young Aeolian deposits .4Lacustrine plain. 


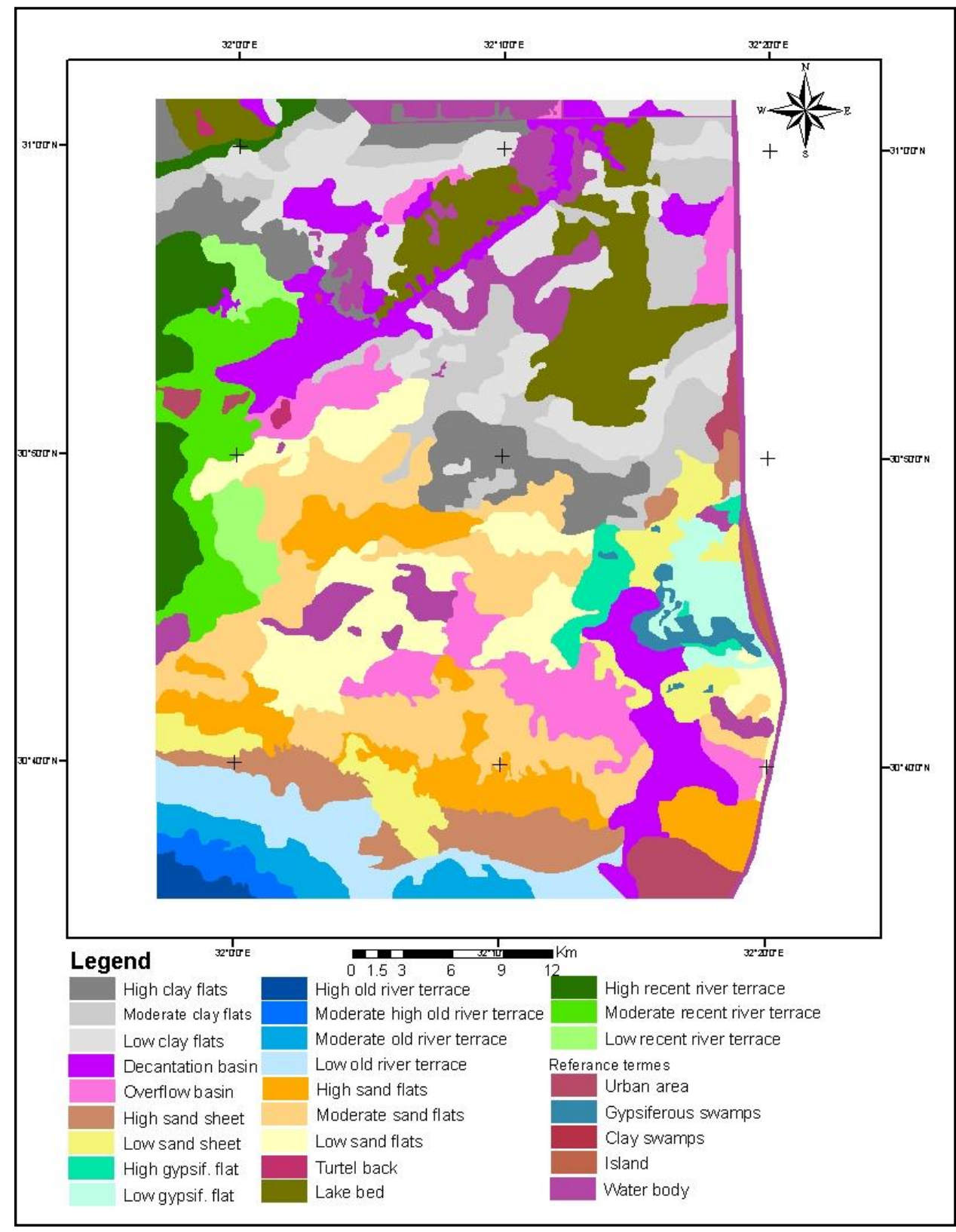

Fig. 3: Geomorphologic map of the studied area (After Mohamed, 2006).

\section{Land capability and suitability assessment.}

This study proposes an integrated methodology for analyzing and mapping of land suitability using the Remote Sensing and GIS techniques. The result indicated that only $18 \%$ of agricultural land can be demarcated as highly suitable for rice cultivation whereas $33 \%$ of agricultural land as highly suitable for wheat cultivation in the study area.

Lands are utilized for multiple purposes. They are mainly used for agriculture, pastures and orchids. Depending on the nature and properties of soils, they are suitable for one or other uses. Based on the capability or limitations, Classification of soils based on land capability helps in estimating soil resources available for different purposes and for appropriate use of soils without deterioration. The percentage of each class is shown in Table 3 and Figure 4.

The land suitability for agriculture ranges from high suitable to permanently unsuitable. Results showed that land units which have no limitations cover small part of the study area. It is possible to assume that chemical and physical soil parameters such as the high surface coarse fragment coverage percentage and the high $\mathrm{CaCO} 3$ values are, in association with the topology, the 
major constraints factors for good land suitability. Most of the unsuitable areas match with moderate slopes, where the soil is shallow and the texture is not helpful for water infiltration. $9 \%$ of the study area is classified as NR (not relevant) because it's including the urban, water body, military camp surfaces.

Table 3. Land capability classification for the study area

\begin{tabular}{cc}
\hline Land Capability & Occupied Area \% \\
C1 & $\mathbf{8 8}$ \\
\hline C2 & 14 \\
C3 & 33 \\
C4 5 & 8 \\
Urban & 2 \\
\hline Water bodies & 7 \\
\hline
\end{tabular}

\section{Soil suitability for crops.}

Aspects of land suitability for the crops and orchards were determined based on climate, soil and topographic variables. The study area was delineated according to suitability classes for wheat, maize, cotton, rice, onion, alfalfa, potato, tomato, citrus growing in the study area as shown in Table 4. These suitability classes are presented in figures 5-13.

Table 4. Land suitability classification for selected crops and citrus.

\begin{tabular}{cccccccccc}
\hline land suitability classes & Wheat & Maize & Cotton & Rice & Onion & Alfalfa & Potato & Tomato & Citrus \\
\hline S1 & 33.07 & 21.14 & 38.12 & 17.97 & 15.30 & 17.97 & 32.20 & 43.77 & 10.74 \\
S2 & 35.57 & 45.44 & 28.47 & 27.20 & 54.07 & 35.86 & 34.42 & 34.78 & 36.33 \\
S3 & 9.90 & 11.97 & 16.72 & 33.38 & 9.18 & 24.73 & 16.84 & 4.91 & 28.69 \\
S4 & 4.91 & 4.91 & 4.91 & 4.91 & 4.91 & 4.91 & 0.00 & 0.00 & 4.91 \\
NS & 7.54 & 7.54 & 2.79 & 7.54 & 7.54 & 7.54 & 7.54 & 7.54 & 10.33 \\
Urban & 1.67 & 1.67 & 1.67 & 1.67 & 1.67 & 1.67 & 1.67 & 1.67 & 1.67 \\
Water bodies & 7.07 & 7.07 & 7.07 & 7.07 & 7.07 & 7.07 & 7.07 & 7.07 & 7.07 \\
\hline Island & 0.25 & 0.25 & 0.25 & 0.25 & 0.25 & 0.25 & 0.25 & 0.25 & 0.25 \\
\hline
\end{tabular}

A climatic suitability assessment was also carried out; results showed that there is an optimal climatic condition for the selected crops. Slope did not affect land suitability very much, either. Therefore the criteria, which defined unsuitability in this area, were based on soil properties.

Wheat is the major crop cultivated in the area. Spatial analysis showed that nearly one third of the total area (33\%) is highly suitable for wheat. However, $35.5 \%$ of the area is moderately suitable. Gravel and soil texture are the main factors for decreasing the suitability. This indicates that more area can be brought under cultivation with improvement in soil conservation and management practices. For onion, rice, alfalfa and maize $15.30 \%, 17.97 \%, 17.97 \%$, and 21.14 of the area were found to be employed in their best uses and nearly $80 \%$ of the region had some kind of limitation. For potato and tomato, there was highly suitable classes occupied and area about $32.20 \%, 43.77 \%$ respectively. Likewise, there is high suitable class for cotton occupied $38.12 \%$ of the investigated area. For orchard (Citrus), there was highly suitable class $10.74 \%$ However, $36.33 \%$ of the area is moderately suitable. Likewise, there is unsuitable (NS) class for all the crops. 


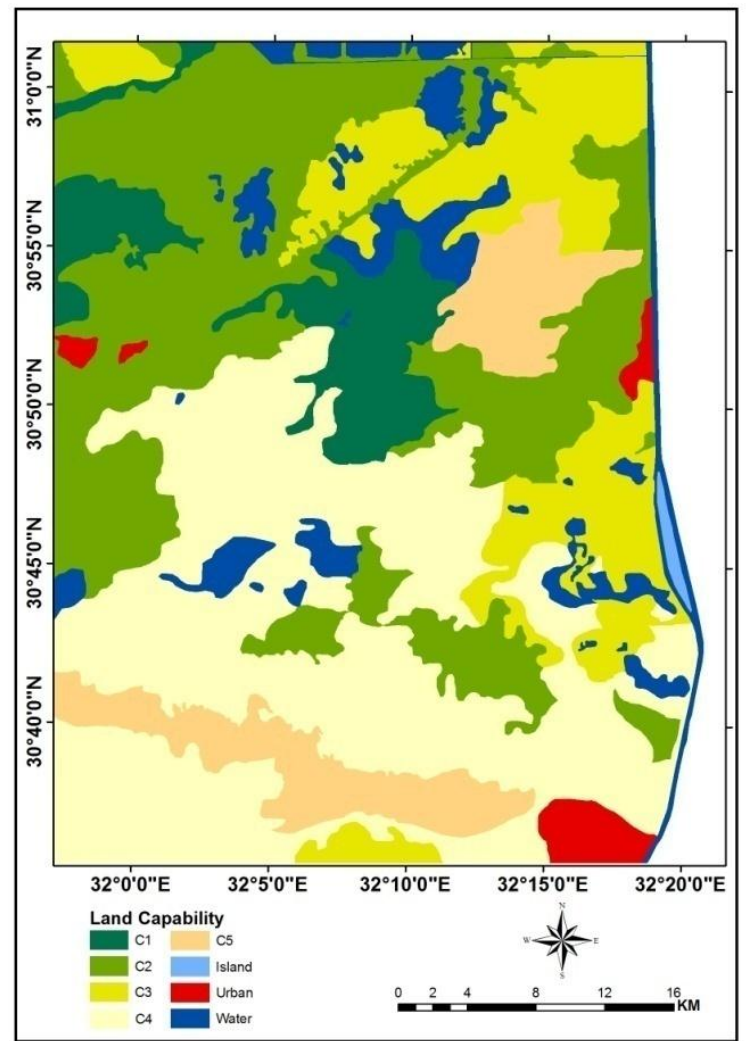

Fig. 4: Land capability map for the study area.

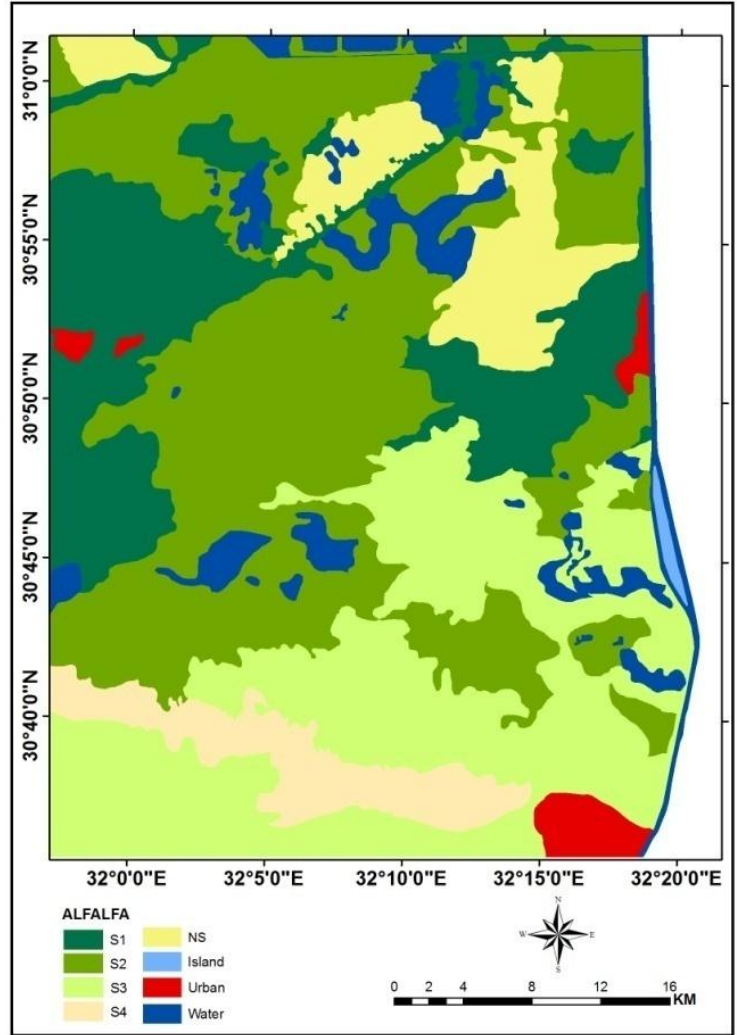

Fig. 6: Land suitability map for Alfalfa.

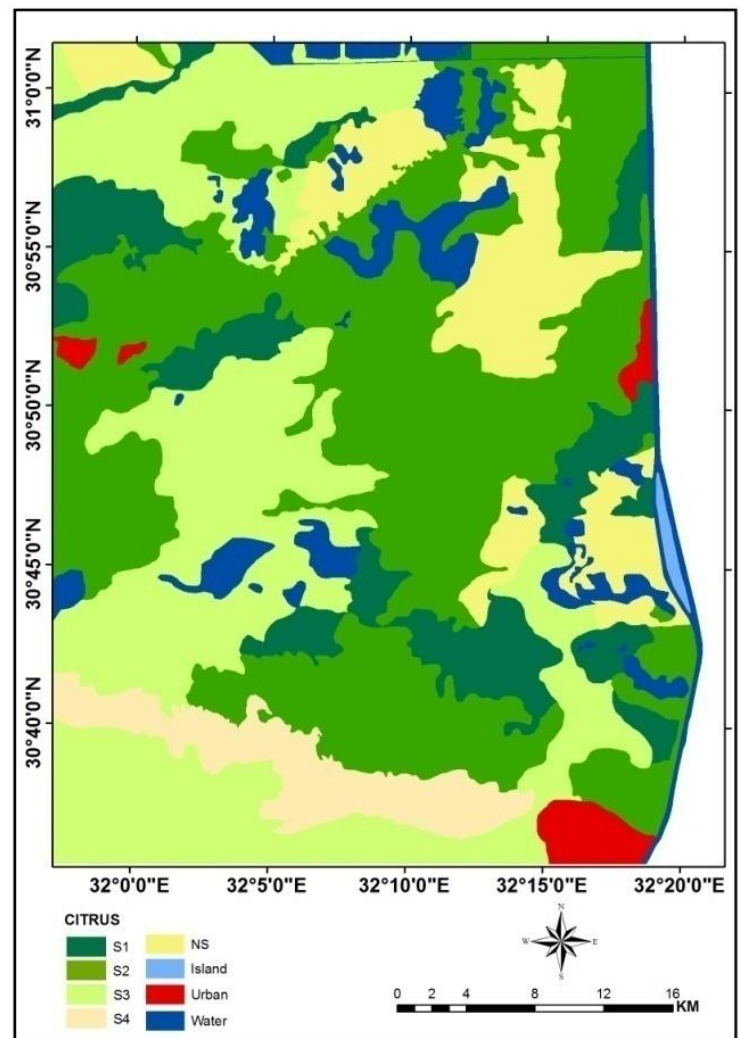

Fig. 5: Land suitability map for citrus.

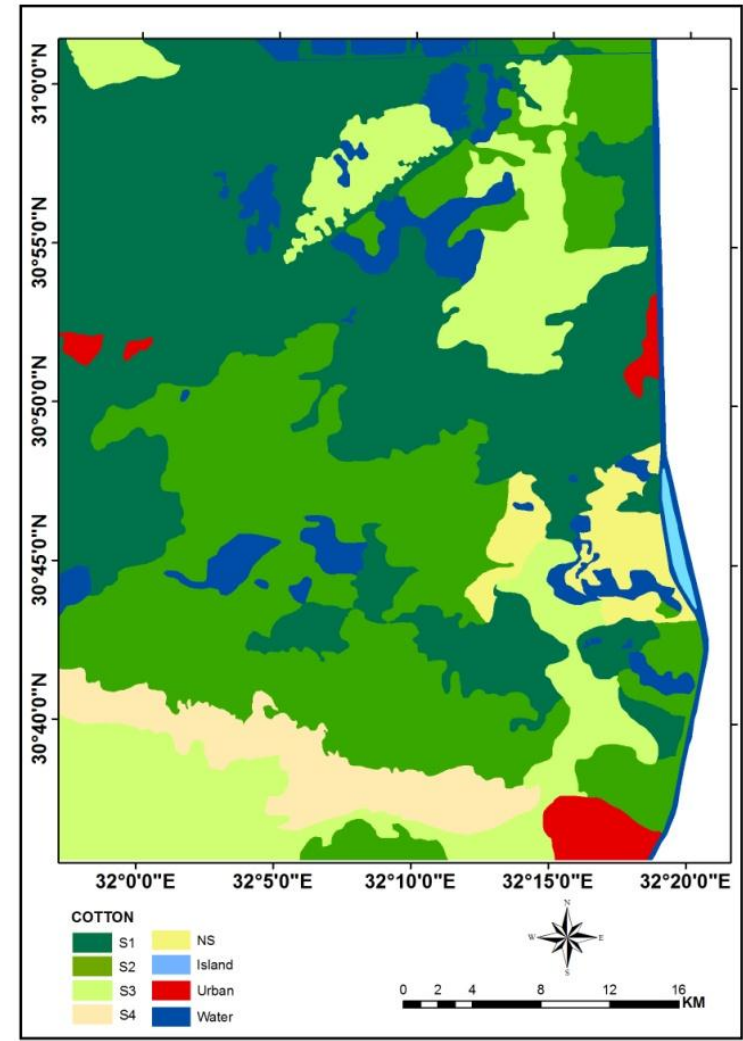

Fig. 7: Land suitability map for cotton 




Fig. 8: Land suitability map for maize.

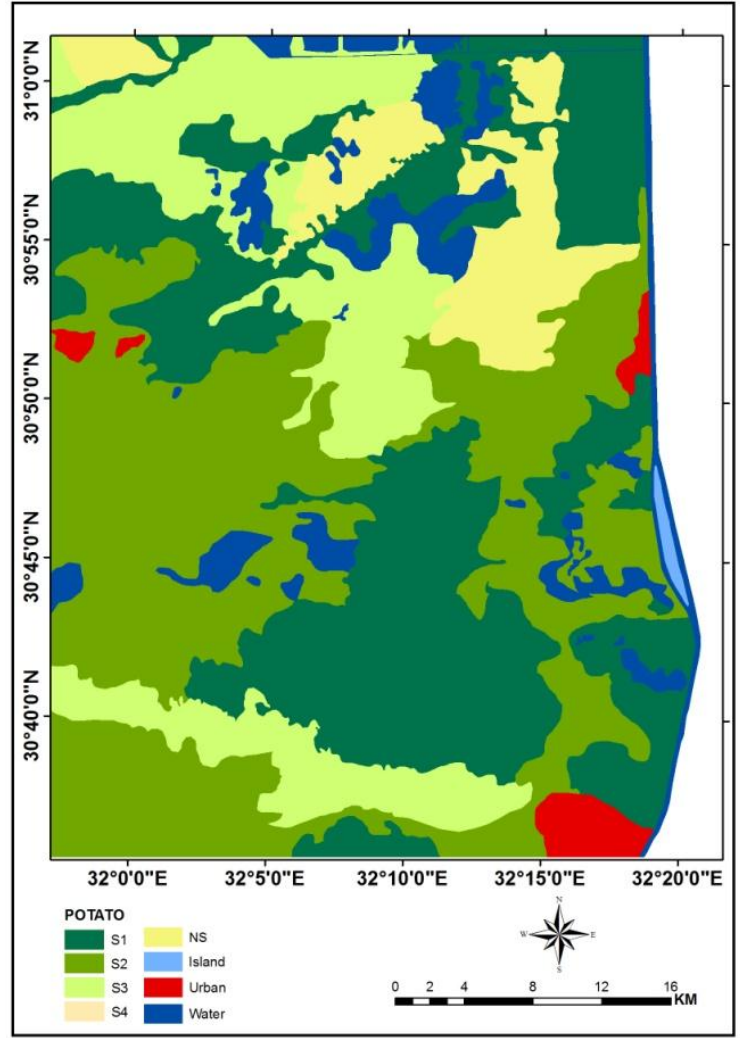

Fig. 10: Land suitability map for potato

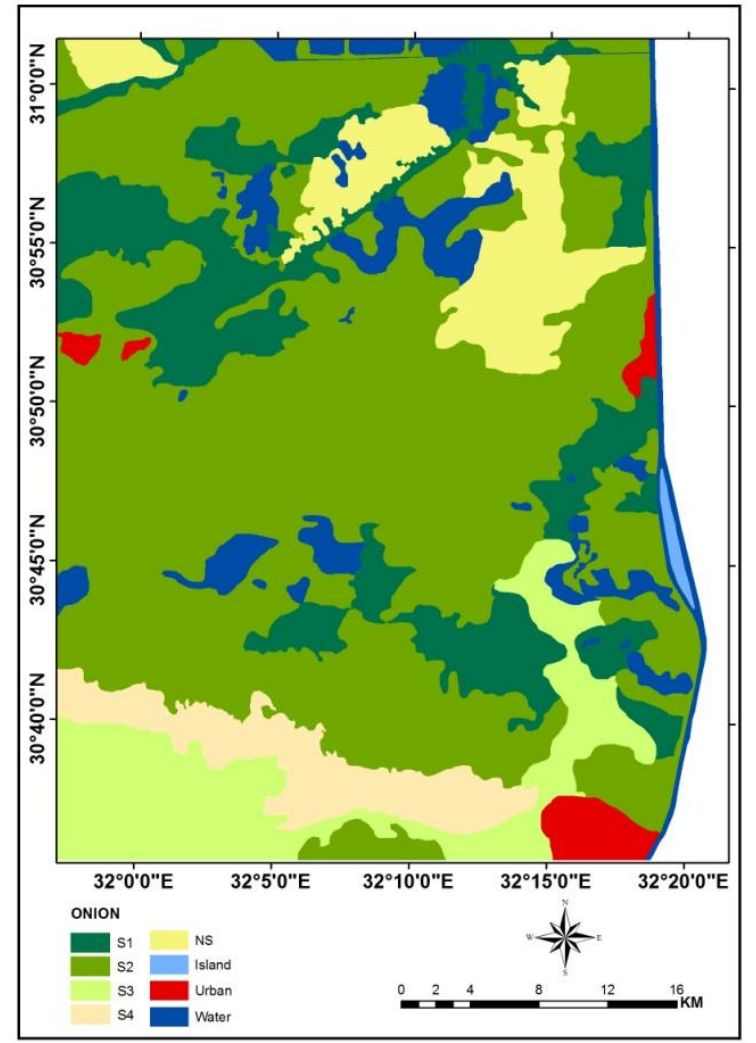

Fig. 9: Land suitability map for onion.

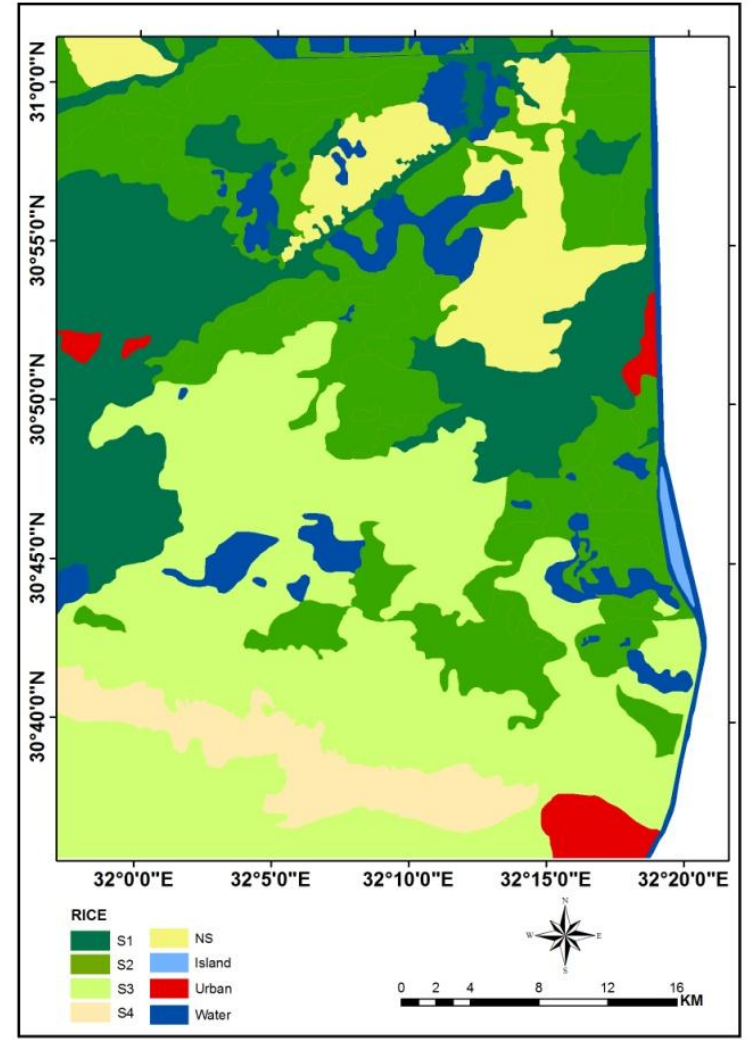

Fig. 11: Land suitability map for rice 


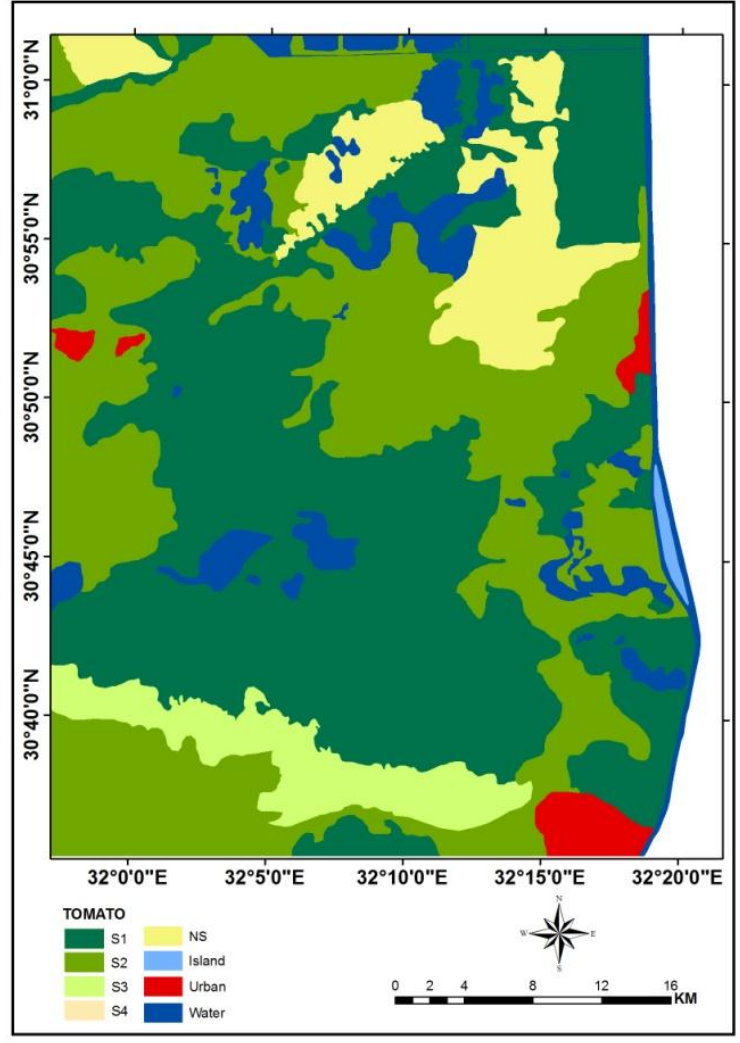

Fig. 12: Land suitability map for tomato. Land suitability assessment model.

To fulfill the aforesaid objectives, Remote Sensing and GIS techniques have been used. The methodology followed in present study can be classified into multisteps (Figure 2). In this paper the classification scheme of land suitability and their rating values have been adopted from proposed classification system of FAO (1976) and Sys et al. (1993).

The land suitability classification, using the guidelines of FAO (1976) is divided into Order, Class, Sub Class,

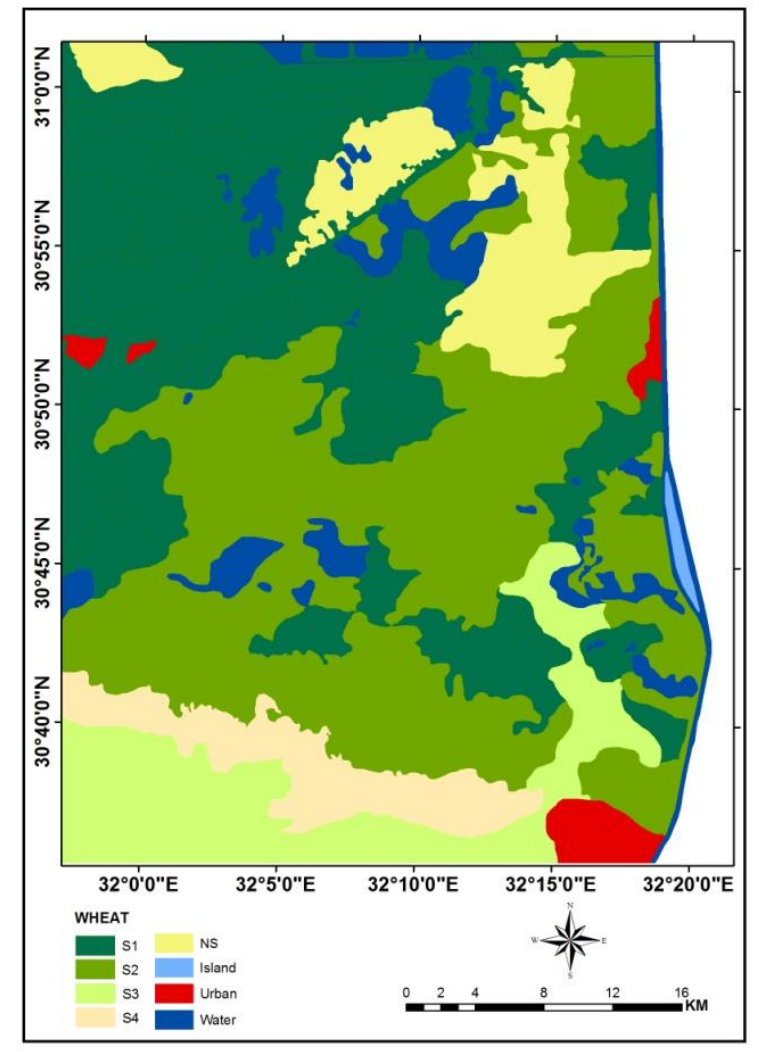

Fig. 13: Land suitability map for wheat.

and Unit. Order is the global land suitability group. Land suitability Order is divided into S (Suitable) and $\mathrm{N}$ (Not Suitable). The weighted value of each land characteristic factors were added and the average value of them were taken to determine the suitability of the land for each land use types. The average value then categorized in to six suitable classes to get the final suitability for each land uses (Table 14). 


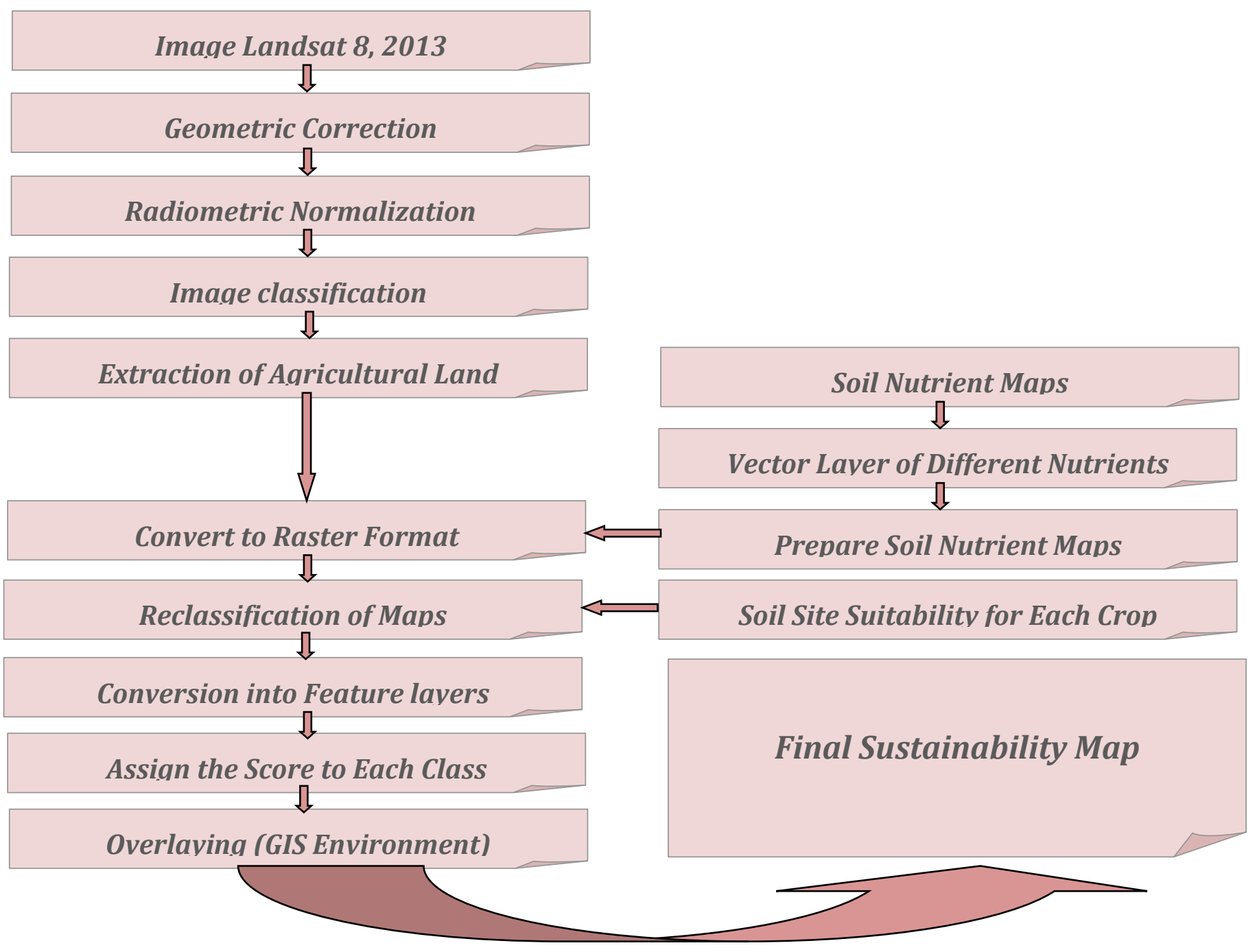

Fig. 2: Flowchart of the methodology followed in the study.

\section{Conclusions}

The land suitability analysis for agriculture is an important piece of information for agricultural development and future planning. A climatic suitability assessment was carried out to consider the optimal climatic condition for the selected crops. Most of the area nearly level therefore slope did not affect land suitability very much. Soil properties were the major criteria, which defined unsuitability in the investigated area. Result showed that nearly one third of the total area $(33 \%)$ is highly suitable for wheat which is the major crop cultivated in the area. However, $35.5 \%$ of the area is moderately suitable. Gravel and soil texture are the main factors for decreasing the suitability. This indicates that more area can be brought under cultivation with improvement in soil conservation and management practices. For orchard (Citrus), there was highly suitable class $10.74 \%$ However, $36.33 \%$ of the area is moderately suitable.

\section{Acknowledgements}

Author would like to express his appreciation to Dr. Mohamed A. E. AbdelRahman, Researcher at National Authority for Remote Sensing and Space Sciences (NARSS), Egypt for his help and contributes to this work.

\section{References}

AdelRahman, M. A. E. 2009. Quantification of land degradation indicators using remote sensing and 
GIS techniques. M. Sc. Thesis submitted to Zagazig University, Egypt.

AdelRahman, M. A. E. 2014. Assessment of land degradation and land use planning using remote sensing and GIS techniques in Chamarajanagar District, Karnataka Ph.D. Thesis submitted to UAS, Bangalore University, India.

Conoco. 1987. Geological map of Egypt, scale 1:50000. Coral Egyptian General petroleum Authority.

Egyptian Meteorological Authority. 1996. Climatic atlas of egypt. Published, Arab Republic of Egypt. Egyptian Meteorological Authority (EMA). Ministry of Transport.

EI-Fayoumy, I. F. 1968. Geology of ground water supplies in the region east of the Nile Delta. Ph. D., Thesis, Fac. of Sci., Cairo Univ., Cairo, Egypt.

Ekanayake, G. K., and N. D. K. Dayawansa. 2003. Land suitability Identification for a production forest though GIS technique. http://www.gisdevelopment.net/application/envi ronment/overview/mi03148.htm.

FAO. 1976. A Framework for Land Evaluation: Soils Bulletin: 32, Food and Agriculture Organization of the United Nations, Rome, Italy.

FAO. 1993. Guidelines for land use planning. Food and Agricultural Organization (FAO). Rome, Italy.

Joerin, F., M. Theriault and A. Musy. 2001. Using GIS and outranking multi-criteria analysis for land use suitability assessment. International Journal of Geographical Information Science, 15: $153-174$.

Landon, J. R. 1991. Booker Tropical Soil Manual. Longman Scientific and Technical. pp. 474.
Mohamed, E. S. 2006. Optimum land use planning for some newly reclaimed soils in west of Suez Canal area, using remote sensing techniques. MSc, soil sciences fac. Agric. Alazhar University, $159 \mathrm{p}$.

Pereira, J. M. C., and L. Duckstein. 1993. A multiple criteria decision-making approach to GIS-based land suitability evaluation. International Journal of Geographical Information Science, 7: 407:424.

Steiner, F., L. McSherry and J. Cohen. 2000. Land suitability analysis for the Upper Gila River Watershed. Land scape and Urban Planning, 50: 199-214.

Sys, C. E., R. Van, J. Debaveye and F. Beernaert. 1993. Land evaluation part III. Crop requirements. Agric. publications No.7. General Administration for Dev. Co-operation, Brussels, Belgium.

Sys, I., E. Van Ranst and J. Debaveye. 1991. Land evaluation, part I. Principles in land evaluation and crop production calculations, General administration for development cooperation, Brussels, pp. 40.

USDA. 2002. Field book for describing and sampling soils. National Resources Conservation Service (NRCS), United State Department of Agriculture, Version 2.

USDA. 2004. Soil survey laboratory methods manual soil survey investigation. Report No. 42, Version 4.0.

USDA. 2010. Keys to soil taxonomy. United State Department of Agriculture, (NRCS), Eleventh Edition.

Zhang, Y. J., A. J. Li and T. Fung. 2011. Using GIS and multi-criteria decision analysis for conflict resolution in land use planning. Procedia Environmental Sciences, 13: 2264-2273. 
تطبيقات الأستثعار عن بعد ونظم المعومات الجغرافية فى تحليل مدى ملائمة إستخدام الأرض.

محمد السيد على1، عمر الحسينى محمد الحسينى1، هبة شوقى عبدالله رالثد1، سيد سعيد محمد2، أمنية حسان السيد سلامةّ2.

اقسم الاراضى والمياه- كلية الزراعة- مشتهر - جامعة بنها- مصر.

| الهيئة القومية للاستشعار عن بعد وعلوم الفضاء - القاهرة - مصر.

التطور السريع لتكنولوجيا الإستثـعار من بعد والنضوج التدريجى لتطبيقات تكنولوجيا نظم المعلومات الجغرافيـة يعتبر الأساس لدراسة مدى ملائهـة أستخدام الأرض من تحليل كيفى (نوعى) الى تحليل كمى ـ استخدام تكنولوجيا الإستشعار عن بعد ونظم المعلومات الجغرافية تعتبر نكنولوجيا حديثة.

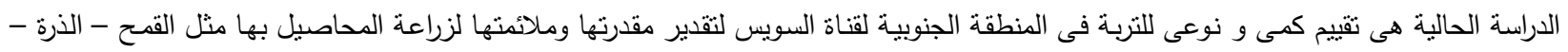

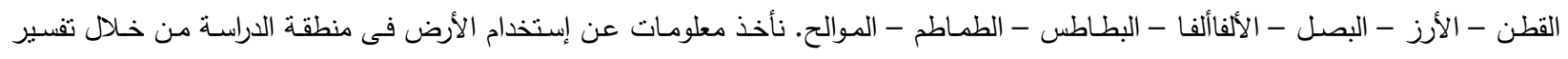

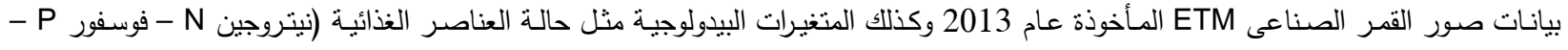

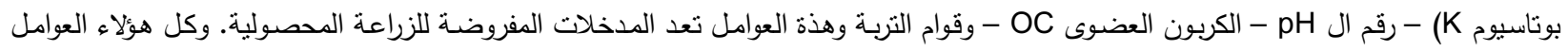

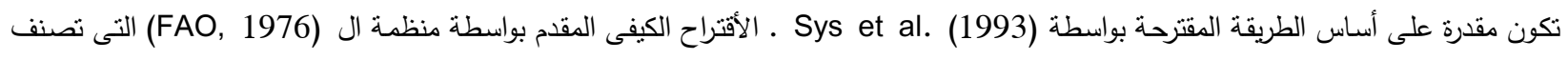

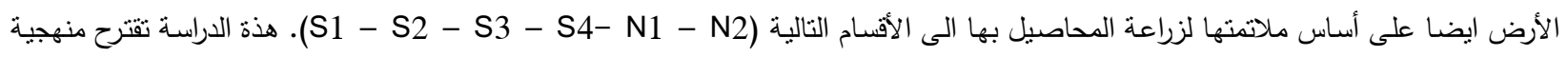

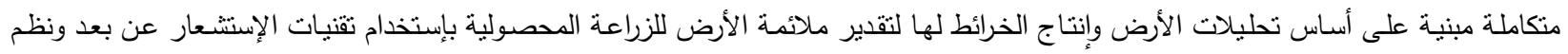

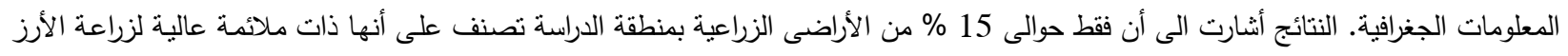
فى حين أن 33 \% من تلك الأراضى تصنف على أنها ذات ملائمة عالية لزراعة القمح. 